\title{
Liquidity Risk Management: A Comparative Study between Conventional and Islamic Banks in Bangladesh
}

MD. LUTFOR RAHMAN*

S. M. HASANUL BANNA**

\begin{abstract}
Liquidity risk may arise from diverse operations of financial intermediaries, facilitators and supporters as they are fully liable to make available liquidity when required by the third party. Incase of Islamic Banks additional efforts are required for scaling liquidity management due to their unique characteristics and conformity with Shariah principles. The objective of this study is to look into the liquidity risk associated with the solvency of the financial institutions, with a purpose to evaluate liquidity risk management (LRM) through a comparative analysis between conventional and Islamic banks of Bangladesh. This paper investigates the significance of Size of the Firm, Net Working Capital, Return on Equity, Capital Adequacy and Return on Assets (ROA), on Liquidity Risk Management in conventional and Islamic banks in Bangladesh. The study has taken six mid-size banks- three conventional and three Islamic banks as samples. It is based on secondary data which are collected from the selected banks' annual reports, covering a period of 2007-2011. Independent variables that have positive but insignificant relation are; size of the bank and net working capital to liquidity risk in Islamic banks and in case of conventional banks size of bank is negatively related with the liquidity risk. Only return on assets is positively affecting the liquidity risk at 10\% level in case of conventional banks, but in Islamic banks the relationship is insignificant. The other variables are found to be insignificant in affecting the liquidity risk for both the conventional and Islamic banks in Bangladesh.
\end{abstract}

Keywords: Liquidity Risk, Return on Assets, Return on Equity, Net Working Capital, Conventional Banks, Islamic Banks.

\footnotetext{
* Associate Professor, Faculty of Business, Northern University Bangladesh, Dhaka. E-mail: mlut4rahman@gmail.com

** Research Assistant, Centre for Management and Development Research (CMDR), Dhaka. E-mail: bannashah13@gmail.com
} 


\section{INTRODUCTION}

The banking sector plays an important role in financing for most of the businesses. For banks, liquidity is the most vital factor related to its survival. In Bangladesh, sometimes there exists access liquidity while sometimes there is liquidity crisis. The ongoing trend in most of the banks is worse liquidity crisis and crowding out effect because of government's excessive borrowings and bad loan given to the businessmen without much considering their ability to generate enough income to pay back the necessary instalments.

An act of exchange of a less liquid asset with a more liquid asset is called liquidation. In general, liquidity is the amount of capital available for investment and spending. For banks, liquidity refers to the ability of it to meet up deposit

withdrawals, maturing loan request and liabilities without setback. ${ }^{1}$ Adequate liquidity depends upon the institution's ability to efficiently meet both expected and unexpected cash flows and collateral needs without adversely affecting either daily operations or the financial condition of the institution. While excess liquidity is bad for a bank, as it does not contribute to the income of the institution, lacking enough liquidity to meet the day to day transactions is more devastating, as it may lead to not only financial loss but to bankruptcy of the institution.

Liquidity risk is defined as the risk to an institution's financial condition or safety and soundness arising from its inability (whether real or perceived) to meet its contractual obligations. The primary role of liquidity-risk management is to (1) prospectively assess the need for funds to meet obligations and (2) ensure the availability of cash or collateral to fulfil those needs at the appropriate time by coordinating the various sources of funds available to the institution under normal and stressed conditions.

Therefore, it is very important to identify the factors which cause the liquidity situation of the banking institutions with respect to Bangladesh. This paper is an attempt to analyze them and compare the factors responsible for the conventional banks vis-à-vis the Islamic banks in Bangladesh.

\subsection{Statement of the Problem}

The required CRR (Cash Reserve Ratio) by the Bangladesh Bank for conventional and Islamic banks is not the same. The factors the management looks at while managing their liquidity, thus should also differ between the two

${ }^{1}$ Metwally, M. (1997)."Differences between the financial characteristics of interest-free banks and conventional banks". European Business Review, pp: 94 
types of banks. In this study, the researchers will try to focus whether any significant differences exist in managing liquidity position of Islamic and conventional banks in Bangladesh. Conventional banking activities started in England many years ago but Islamic banking concept is a new one compared to conventional banking. Likewise in the preceding decade worldwide growth rates of $10 \%$ to $15 \%$ per annum has been experienced by Islamic banking sector, providing it lucrative avenues for expansion of businesses even in the western world. In this paper the researchers will also try to identify the ongoing liquidity risk condition for both the conventional and Islamic banks in Bangladesh.

\subsection{Objective of Study}

The objective of this study is to determine how liquidity risk is associated with the solvency of a financial institution, with a purpose to evaluate liquidity risk management (LRM) through a comparative analysis between conventional and Islamic banks of Bangladesh. This paper investigates the significance of Size of the firm, networking capital, return on equity, capital adequacy and return on assets (ROA), as the variables determining the liquidity risk management for both conventional and Islamic banks in Bangladesh.

\section{LITERATURE REVIEW}

A vast set of literature have been available for analysis in countries around the world to determine the performance of Islamic banks and how Islamic banking scheme can offer liquidity and support in the process of money creation beside contributing to transactions accounts and found that in all developing economies investing funds on basis of profits and losses is an attractive choice for the banks (Ghannadian and Goswami, 2004).Liquidity risk can be controlled in the course of practices that are severely connected to the scale and scope of financial measures, seeing as large banks are capable both to manage additional market information and to influence monetary policy functions (Gabbi, 2004).

Studies indicate that liquidity risk exists due to high short-term spread between deposits and loan ratios, high off-balance sheet exposure resulted from financial engineering by the conventional banks, asset-liability duration mismatch and relatively lower investment in risk-free government assets (bonds). (Zheng, 2006 \& Ayub, 2007). The commercial banks generally sell the deposit products that are liquid and short term based, the loan products, which are assets to the banks, are less liquid and long-term based which is the prime reason liquidity mismatch. (Akhizidis \& Khandelwal, 2008). 
Study by Hassan (2009) asserted that there are 3 types of risk faced by the Islamic banks in Brunei Darus Salam. These include credit risk, foreignexchange rate risk, and operating risk. These risks are managed by such practices as Risk Identification (RI) and Risk Assessment Analysis (RAA). Study on Indonesia (Ismal, 2010) found that with respect to liquidity management in the Islamic banks in Indonesia, they evaluate themselves on the basis of three factors such as, banks liquidity management policy, liability side and asset side, and they stand in the index of good grade. Conventional banks in Pakistan were more tend on the way to considering projects with long-term financing. In addition they found that superior performance in elements of assets and return confirmed that they had better profitability and liquidity risk management than Islamic banks (Akhter \& Sadaqat, 2011). The model used by them has been adapted for the current research.

The regression model used by Sawada (2010) highlighted the size of the bank as positively related with liquidity risk. The result of this study is in accordance with the previous studies as found by this research authenticate that the size of the bank is positive and insignificant when cash-to-asset ratio is used as dependent variable. Ojo (2010) described the value of capital adequacy ratio as defined in the Basel II accord as a measure to reduce risk. This study found capital adequacy ratio to be positive and statistically significant in conventional banks (Model 1 used by the present authors), also supported by (Sensarma \& Jayadev, 2009).However capital adequacy ratio is insignificant in case of Islamic banks. (Tarawneh, M 2006) Though, results of this pragmatic study are in line with that of (Rosly \& Zaini, 2008) who found that return on equity does not imitate risk-taking features. This paper shows positive and significant relation with Islamic banks but positive and insignificant with conventional banks. These results are in accordance with the findings of (Siddiqui, 2008).

The above review of literature suggests that liquidity risk does not always significantly depend upon every independent variable. For example Capital Adequacy Ratio and Return on Equity is insignificant in case of both Islamic banks and conventional banks. Liquidity risk varies on different variables because of size of bank differs from banks to banks. While there are lots of works being done on both Islamic and conventional banks all over the world but not much works have been done in Bangladesh. 


\section{RESEARCH METHODOLOGY}

\subsection{Measures of Variables}

Liquidity risk is considered as the dependent variable for this study. Explanation of dependent and independent variables along with their proxies and a figure is specified below. In addition, the list of Islamic and conventional banks that are considered for this study is specified under Appendix A1.

Figure 1: Variables Determining the Liquidity Risk (Source: Akhter \& Sadaqat, 2011).

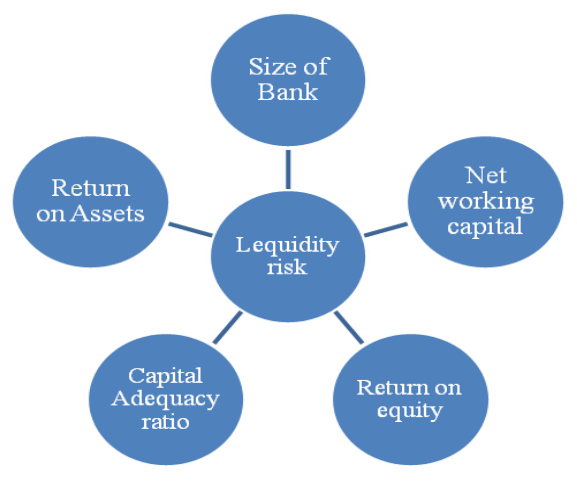

TABLE 3.1.1

VARIABLES AND THEIR PROXIES

\begin{tabular}{lll}
\hline Symbol & \multicolumn{1}{c}{ Variables } & \multicolumn{1}{c}{ Proxies } \\
\hline $\boldsymbol{Y}_{\mathbf{1}}$ & Liquidity Risk & Cash to Total Assets \\
$\boldsymbol{X}_{1}$ & Size of the Bank & Logarithm of total assets \\
$\boldsymbol{X}_{2}$ & Net working Capital & Current asset less current liabilities \\
$\boldsymbol{X}_{3}$ & Return on Equity & Net income/ total equity \\
$\boldsymbol{X}_{4}$ & Capital Adequacy Ratio & (Tier 1 capital + Tier 2 capital ) / risk weighted \\
$\boldsymbol{X}_{5}$ & Return on Assets & asset \\
$€$ & Error term & Net income / Total asset \\
\hline
\end{tabular}

Liquidity risk is the dependent variable of this study whereas Size of the Bank (size), Net Working Capital (NWC), Return on Equity (ROE), Capital Adequacy Ratio (CAR), and Return on Assets (ROA) are the independent variables. 


\subsection{Research Model \& Hypothesis}

The current research is being conducted to evaluate how liquidity risk depends upon different variables by applying linear regression model which already been developed and applied by Akhter \& Sadaqat (2011). Utilizing the similar model this study focuses on what variables are to be considered to manage liquidity risk in both conventional and Islamic banks. Current research model as follows:

$$
Y_{1}=\alpha+\beta_{1} X_{1}+\beta_{2} X_{2}+\beta_{3} X_{3}+\beta_{4} X_{4}+\beta_{5} X_{5}+€
$$

Model 1 and model 2 are specified models for conventional and Islamic bank respectively.

\section{Model 1:}

$Y_{1 c}=\alpha+\beta_{1 c} X_{1 c}+\beta_{2 c} X_{2 c}+\beta_{3 c} X_{3 c}+\beta_{4 c} X_{4 c}+\beta_{5 c} X_{5 c}+€$

\section{Model 2:}

$Y_{1 I}=\alpha+\beta_{1 I} X_{1 I}+\beta_{I 2} X_{2 I}+\beta_{3 I} X_{3 I}+\beta_{4 I} X_{4 I}+\beta_{I 5} X_{5 I}+€$

The regression will be run separately for both the Islamic and the conventional banks for the stated variables. Therefore, the hypotheses that need to be tested are as follows:

i. There is a significant relationship between the liquidity risk with the independent variables for both Islamic and conventional banks.

ii. There is a significant relationship liquidity risk with Size of bank.

iii. There is a significant relationship liquidity risk with Net Working Capital.

iv. There is a significant relationship liquidity risk with Return on Equity.

v. There is a significant relationship liquidity risk with Capital Adequacy Ratio.

vi. There is a significant relationship liquidity risk with Return on Assets.

\subsection{Sample \& Data Collection}

To achieve the research objectives, this paper uses a sample of 6 banks, of which 3 are conventional banks and 3 are Islamic banks. The banks were selected not only on the basis of availability of data but also based on their sizes. In this study we will consider mid-size banks for both conventional and Islamic. Data were collected from the bank's annual reports over the period 2007-2011. This paper fully depends on secondary data. Financial data from these annual reports 
are used to calculate and to evaluate the liquidity risk management in conventional and Islamic banks of Bangladesh.

\subsection{Procedure for Data Analysis}

Different financial tools and techniques namely maximum, minimum, range, mean, standard deviation, coefficient of variation, Pearson's correlation, multiple regression etc. have been used here to analyze the collected data and make the comparison. Using multiple regression analysis findings are presented based on types of banks. SPSS V 16.0 is used in investigating, measuring and comparing the liquidity risk for conventional and Islamic banks according to their diverse individuality.

\section{FINDINGS AND ANALYSIS}

Liquidity is the ability to meet any instant need in the form of cash or cash equivalent by selling assets; as it is known as the most liquid asset by its nature. The bank must keep sufficient amount in reserves to cover any unavoidable circumstance of economy. The statistical analysis of secondary data has been divided into three dimensions, i.e. descriptive, correlation and regression.

\subsection{Descriptive Statistics}

The descriptive analysis below shows the maximum, minimum, Range, mean, standard deviation values of conventional and Islamic banks.

TABLE 4.1.1

\section{SUMMARY STATISTICS}

\begin{tabular}{l|c|c|c|c|c|c|c|c|c|c}
\hline \multicolumn{10}{c}{ Descriptive statistics(Conventional \& Islamic banks) } \\
\hline $\mathrm{V}$ & \multicolumn{2}{c}{ Minimum } & \multicolumn{2}{c|}{ Maximum } & \multicolumn{2}{c}{ Range } & \multicolumn{2}{c|}{ Mean } & \multicolumn{2}{c}{ Std. deviation } \\
\hline Bank & con & Isl & con & isl & con & isl & con & isl & con & Isl \\
\hline LR & .0513 & .0554 & .0820 & .1149 & .0307 & .0595 & .06841 & .8088 & .00939 & .0176 \\
Size & 17.28 & 23.92 & 26.02 & 25.58 & 8.74 & 1.66 & 24.68 & 24.79 & 2.1040 & .5197 \\
$\mathrm{NWC}$ & 2.82 & 1.05 & 23.62 & 16.83 & 20.80 & 15.78 & 9.620 & 6.52 & 6.555 & 4.52 \\
$\mathrm{ROE}$ & .0839 & .0901 & .2789 & .3070 & .1950 & .2169 & .1939 & .1897 & .05838 & .0675 \\
$\mathrm{CAR}$ & .0630 & .0933 & .1471 & .1398 & .0841 & .0465 & .10968 & .1099 & .01932 & .0132 \\
ROA & .0052 & .0061 & .2259 & .0305 & .2207 & .0244 & .03432 & .0176 & .05889 & .0007 \\
\hline
\end{tabular}

Here,

$\mathrm{LR}=$ Liquidity risk, Size $=$ Size of Bank, NWC $=$ Net Working Capital, ROE $=$ Return on Equity, CAR= Capital Adequacy Ratio, ROA= Return on Assets, V= variable, Isl $=$ Islamic Con $=$ conventional 
From the above Table we can identify different variables such as the minimum value of conventional bank's LR, Size, ROE, CAR, ROA are less than that of Islamic banks but only NWC is greater than that of Islamic banks. Maximum value of Size, ROE, and CAR in conventional banks' are also greater than Islamic banks. Range of LR, ROE are less in conventional banks compare with Islamic banks and other variables are greater in Islamic banks as well. Standard deviation of Islamic banks' in Size, NWC, CAR and ROE is less than conventional banks which indicate lower risk and more stability.

\subsection{Correlation Matrix}

The correlation coefficients are stated under appendix A2 at the end of this article. This gives information on the degree of correlation between the explanatory variables. The opportunity has been tested with the Pearson correlation coefficients test. The matrix explains that in general the correlation between the explanatory variables is not well-built that multicollinearity problems are not severe. Kennedy (2008) identified that multicollinearity is a problem when the correlation is above 0.705 .

According to the correlation results, the size of bank is positively correlated with net working capital, return on equity, capital adequacy ratio and return on assets but found insignificant with liquidity risk in conventional but in Islamic all are positive but Net working capital and return on assets are significant at $5 \%$ \& $1 \%$ level.Net working capital is positively correlated and insignificant with return on equity, capital adequacy ratio and return on assets in conventional banks. But in Islamic banks net working capital is positively correlated with return on equity and negatively correlated with capital adequacy ratio. Net working capital is strong positively correlated and also significant with return on asset at $5 \%$ level. Return on equity negatively correlated with capital adequacy ratio and positively correlated with return on assets which is weak and insignificant in conventional banks but positive in Islamic banks. Here capital adequacy ratio is not significant but return on assets is significant at $5 \%$ level. Capital adequacy ratio is positively correlated and insignificant with return on assets in both banks but in conventional moderate positive and Islamic weak positive correlation. 


\subsection{Regression Analysis}

As far as regression results with the Islamic and conventional bank's liquidity risk are concerned the following analysis is based on the regression results obtained from SPSS output. Quite acceptable value of $\mathrm{R}^{2}$ for both model explain that the independent variables explains about $45 \%$ and $68 \%$ changes in the dependent variables for conventional and Islamic banks respectively . ROE is found to be correlated with ROA in Islamic Banking (Model 2). Whereas in conventional banks these variables are perfectly independent, as suggested by Pearson correlation coefficients. Hence the critically developed models reflects on the outcome of size of the bank, networking capital, return on equity, capital adequacy ratio and return on assets in both models, i.e. conventional banks (Model 1), and Islamic banking (Model 2).

TABLE 4.3.1

\section{REGRESSION RESULTS FOR LIQUIDITY RISK}

\begin{tabular}{|c|c|c|c|c|c|}
\hline \multicolumn{6}{|c|}{ Coefficients ${ }^{\mathrm{a}}$ Model- 1 (Conventional banks) } \\
\hline & \multicolumn{2}{|c|}{ Unstandardized Coefficients } & \multirow{2}{*}{$\begin{array}{c}\begin{array}{c}\text { Standardized } \\
\text { Coefficients }\end{array} \\
\text { Beta }\end{array}$} & \multirow[t]{2}{*}{$\mathrm{t}$} & \multirow[t]{2}{*}{ Sig. } \\
\hline & B & Std. Error & & & \\
\hline (Constant) & \multicolumn{2}{|r|}{.034} & & 3.040 & .014 \\
\hline Size of bank & .000 & .001 & -.177 & -.569 & .583 \\
\hline Net working capital & .000 & .000 & .130 & .441 & .670 \\
\hline Return on equity & .044 & .047 & .274 & .930 & .377 \\
\hline Capital adequacy Ratio & \multicolumn{2}{|l|}{-.267} & -.549 & -1.761 & .112 \\
\hline Return on Assets & \multicolumn{2}{|l|}{.089} & .556 & 1.837 & .099 \\
\hline \multicolumn{6}{|l|}{$\begin{array}{l}\mathrm{R}=.667 \\
\mathrm{R} \text { Square }=.446 \\
\text { Adjusted R Square }=.137 \\
\text { F-statistic }=1.446\end{array}$} \\
\hline \multicolumn{6}{|c|}{ Coefficients $^{\mathrm{a}}$ Model -2(Islamic banks) } \\
\hline & \multicolumn{2}{|c|}{ Unstandardized Coefficients } & $\begin{array}{l}\text { Standardized } \\
\text { Coefficients }\end{array}$ & \multirow[t]{2}{*}{$\mathrm{t}$} & \multirow[t]{2}{*}{ Sig } \\
\hline & B & Std. Error & Beta & & \\
\hline (Constant) & -.215 & .351 & & -.612 & .555 \\
\hline Size of bank & .012 & .015 & .358 & .812 & .438 \\
\hline Net Working Capital & .001 & .002 & .355 & .642 & .537 \\
\hline Return on Equity & .033 & .093 & .124 & .349 & .735 \\
\hline Capital Adequacy Ratio & -.239 & .280 & -.179 & -.854 & .415 \\
\hline Return on Assets & .253 & 1.124 & .108 & .225 & .827 \\
\hline \multicolumn{6}{|l|}{$\begin{array}{l}\mathrm{R}=.826 \\
\mathrm{R} \text { Square }=.683 \\
\text { Adjusted R Square }=.507 \\
\text { F-statistic }=3.84\end{array}$} \\
\hline a. Dependent Variable: Lic & & & & & \\
\hline
\end{tabular}


TABLE 4.3.2

SIGNS OF COEFFICIENTS FOR INDEPENDENT VARIABLES

(CONVENTIONAL BANKS)

\begin{tabular}{l|l}
\hline Sign & Variables \\
\hline Positive & Net Working Capital, Return on Equity, Return on Assets \\
Negative & Size of bank, Capital Adequacy Ratio \\
\hline
\end{tabular}

Though the sign of size of bank \& Capital adequacy Ratio are supposed to be positively related with liquidity risk but this research these factors are negatively related, through statistically insignificant. The only variable to be statistically significant is Return on Assets at $10 \%$ level. In general therefore, the equation becomes:

\section{liqiuidity risk}

$$
\begin{aligned}
& =.104+(-0.177) \text { size of bank } \\
& +(0.130) \text { net working capital } \\
& +(0.274) \text { Return on Assets } \\
& +(-0.549) \text { Capita adequacy ratio } \\
& +(0.556) \text { Return on Assets }
\end{aligned}
$$

The $\mathrm{t}$-values of this equation are respectively $3.40^{* *},-549,0.441,0.930$, 1.761 , and $1.837^{*}$

* Significant at $10 \%$ level

** Significant at $5 \%$ level

The findings indicate for $1 \%$ change in Size of Bank results in $28.1 \%$ change in Liquidity Risk.

The findings indicate for $1 \%$ change in Net Working Capital results in $23.4 \%$ change in Liquidity Risk.

The findings indicate for $1 \%$ change in Return on Equity results in $37.8 \%$ change in Liquidity Risk.

The findings indicate for $1 \%$ change in Capital Adequacy Ratio results in $65.3 \%$ change in Liquidity Risk.

The findings indicate for $1 \%$ change in Return on Assets results in $66 \%$ change in Liquidity Risk. 
TABLE 4.3.3

SIGNS OF COEFFICIENTS FOR INDEPENDENT VARIABLES

(ISLAMIC BANKS)

\begin{tabular}{l|l}
\hline Sign & Variables \\
\hline Positive & $\begin{array}{l}\text { Net Working Capital, Return on Equity, Return on Assets, Capital } \\
\text { Adequacy Ratio }\end{array}$ \\
Negative & Size of bank \\
\hline
\end{tabular}

Though the sign Capital adequacy Ratio is supposed to be positively related with liquidity risk but this research these factors is negatively related, through statistically insignificant. There is no variable to be statistically significant. In general therefore, the equation becomes:

\section{liqiuidity risk}

$$
\begin{aligned}
& =-.215+(.358) \text { size of bank } \\
& +(0.355) \text { net working capital } \\
& +(0.124) \text { Return on Assets } \\
& +(-.179) \text { Capita adequacy ratio } \\
& +(0.108) \text { Return on Asset }
\end{aligned}
$$

The $\mathrm{t}$-values of this equation are consecutively $-0.612,0.812,0.642,0.349$,0.854 and 0.225 .

Here t-values are insignificant.

The findings indicate for $1 \%$ change in Size Of Bank results in $57.3 \%$ change in Liquidity Risk.

The findings indicate for $1 \%$ change in Net Working Capital results in 57\% change in Liquidity Risk.

The findings indicate for $1 \%$ change in Return on Equity results in $33.9 \%$ change in Liquidity Risk.

The findings indicate for $1 \%$ change in Capital Adequacy Ratio results in $39.4 \%$ change in Liquidity Risk.

The findings indicate for 1\% change in Return on Assets results in $32.3 \%$ change in Liquidity Risk.

The regression results associated with the Conventional banks' liquidity risk model, the R-square is certainly insignificant (45\%).Around $45 \%$ of the changes in the dependent variable liquidity risk can be explained by the regression equation. The relatively lower F-value is an indication that the formed regression 
equation is not able to predict the liquidity risk condition of the Islamic banks at a statistically significant level. Size of the bank and Capital adequacy Ratio influence the dependent variable in an inverse manner (liquidity risk of the Islamic banks increases if the values of these independent variable decreases and vice versa); on the other hand, net working capital, return on equity and return on assets influence the dependent variable in an positive manner (liquidity risk of the Islamic banks increases if the values of these independent variable increases and vice versa). On a relative scale, net working capital of the firm is the most influencing predictor and capital adequacy ratio is the least. Only net working capital is the statistically significant predictor variable that cannot be left out from the multiple regressions under any circumstances.

The regression results associated with the Islamic bank's liquidity risk model, the R-square is found to be significant (68\%), so around $68 \%$ of the changes in the dependent variable (liquidity risk) can be explained by the regression. The relatively higher F-value is an indication that the formed regression equation is able to predict the liquidity risk condition of the Islamic banks at a statistically significant level. Capital adequacy ratio influence the dependent variable in an inverse manner (liquidity risk of the Islamic banks increases if the values of these independent variable decreases and vice versa); on the other hand size of the bank, Net working capital, return on equity and return on assets influence the dependent variable in a positive manner (liquidity risk of the Islamic banks increases if the values of these independent variable increases and vice versa). On a relative scale, net working capital and size of the firm is the most influencing predictor and capital adequacy ratio is the least. Size of the firm and net working capital are the statistically significant predictor variable that cannot be left out from the multiple regressions under any circumstances.

\section{CONCLUSIONS}

This study is based on the data published in the annual reports of 3 conventional and 3 Islamic banks in banks in Bangladesh. The study takes liquidity risk as the dependent variable and size of bank, net working capital, return on equity, capital adequacy ratio, and return on assets as the independent variables. In descriptive statistics the study found standard deviation of Islamic banks is less than conventional banks in different variables but range is greater in Islamic banks compare with conventional banks. Using linear regression technique the study also found that F-statistic of model-1 is 1.44 and which is insignificant. On the other hand the F-statistic of model-2 is 3.84 and which is

significant at $5 \%$ level. The core purpose of this very research was to develop a 
predictor model for estimating liquidity risk for Bangladeshi Islamic banks and conventional banks. Regression coefficients did not always confine to their expected sign and the extent of the coefficients did vary between different banking systems.

This study also examined liquidity risk management through a comparative study between conventional and Islamic banks of Bangladesh. This points out that both models are good fit. Independent variables that have positive but insignificant relation are; size of bank and net working capital to liquidity risk in Islamic banks. In conventional banks size of bank is negative. Only return on assets is significantly effect on liquidity risk at $10 \%$ level in conventional banks but in Islamic banks it is insignificant. Return on equity in conventional banks and Islamic banks are positive and also insignificant. In addition capital adequacy ratio in conventional and Islamic banks found to be negative. For conventional banks, a model estimation to predict the liquidity risk level was proven to be successful but the model failed to generate the desired result in case of the Islamic banks. Liquidity risk is an ever present hazard for both Islamic and conventional sort of banks irrespective of the difference between their business model.

\section{RECOMMENDATIONS}

The regression analysis shows that some of the variables are insignificantly affecting the liquidity risk. Variables are insignificant not because they don't affect liquidity risk, rather because the data used are insufficient to show such conclusion. Furthermore more variables could be considered for improving the reliability of the model.

The finding on return on assets significantly affecting liquidity risk for conventional banks indicates they should provide proper emphasis on return on assets to reduce their liquidity risk. For the future researchers, this paper suggests that the study should try to include more variable and large sample size for more reliable results. 


\section{REFERENCES}

Akkizidis \& Khandelwal, S. (2008) Financial Risk Management for Islamic Banking and Finance. New York: Palgrave Macmillan.

Akhter \& Sadaqat (2011). "Liquidity Risk Management: A comparative study between Conventional and Islamic Banks of Pakistan". Interdisciplinary Journal of Research in Business Vol. 1, Issue. 1, January 2011(pp.35-44)

Ayub, M. (2007) Understanding Islamic Finance. John Wiley \& Sons.

Franck, R., \& Krausz, M. (2007)."Liquidity risk and bank portfolio allocation". International Review of Economics and Finance, 60-77.

Greuning, H. \& Iqbal, Z. (2008) Risk Analysis for Islamic Banks. Washington DC: The World Bank Publisher.

Gabbi, G. (2004). "Measuring Liquidity Risk in a Banking Management Framework".Managerial Finance, 30, 44-58.

Ghannadian, F. F., \& Goswami, G. (2004)."Developing economy banking: the case of Islamic banks". International Journal of Social Economics, 740-752.

Ismal, R. (2010)."Assessment of liquidity management in Islamic banking industry". International Journal of Islamic and Middle Eastern Finance and Management, 147-167.

Ismal, R. (2010). "Strengthening and improving the liquidity management in Islamic banking". Humanomics, 18-35.

Khasyap, A., R. Rajan and J. Stein (1999), "Banks as Liquidity Providers: An Explanation for the Co-existence of Lending and Deposit-Taking", Working Paper No.6962, NBER.

Mainelli, M. (2008)."Liquidity 5 Diversity". The Journal of Risk Finance, 211-216.

Ojo, M. (2010). "Risk management by the Basel Committee: Evaluating progress made from the 1988 Basel Accord to recent developments". Journal of Financial Regulation and Compliance, 18, 305-315.

Rosly, S. A., \&Zaini, M. A. (2008). "Risk-return analysis of Islamic banks' investment deposits and shareholders' fund'. Managerial Finance, 695-707.

Sawada, M. (2010). "Liquidity risk and bank portfolio management in a financial system without deposit insurance: Empirical evidence from prewar Japan". International Review of Economics and Finance, 392-406.

Sensarma, R., \& Jayadev, M. (2009). "Are bank stocks sensitive to risk management?". The Journal of Risk Finance, 7-22.

Siddiqui, A. (2008). Financial contracts, risk and performance of Islamic banking. Managerial Finance, 34 (10), 680-694.

Tarawneh, M. (2006). "A Comparison of Financial Performance in the Banking Sector: Some Evidence from Omani Commercial Banks". International Research Journal of Finance and Economics, 101-112.

Zheng, H. (2006). "Interaction of credit and liquidity risks: Modelling and valuation". Journal of Banking \&Finance, 391-407. 
APPENDIX A1

LIST OF BANKS INCLUDED IN THE STUDY

\begin{tabular}{l|l|l|l}
\hline \multicolumn{2}{c|}{ Conventional Banks } & \multicolumn{2}{c}{ Islamic Banks } \\
\hline Short Name & \multicolumn{1}{c}{ Full Name } & Short Name & \multicolumn{1}{c}{ Full Name } \\
\hline MTB & Mutual Trust Bank Ltd. & EXIM & EXIM Bank Ltd. \\
PRIME & Prime Bank Ltd. & SHAHJALAL & $\begin{array}{l}\text { Shahjalalislami } \\
\text { bank ltd. }\end{array}$ \\
UCBL & United Commercial Bank Ltd. & SIBL & $\begin{array}{l}\text { Social Investment } \\
\text { Bank Ltd. }\end{array}$ \\
\hline
\end{tabular}

APPENDIX A2

\section{DESCRIPTIVE ANALYSIS OF LIQUIDITY RISK AND ITS MANAGEMENT FACTORS (CONVENTIONAL BANKS)}

\begin{tabular}{|c|c|c|c|}
\hline \multicolumn{4}{|c|}{ Year wise performance (2007-2011) } \\
\hline \multicolumn{4}{|c|}{ Liquidity Risk (\%) } \\
\hline Year & MTB & PRIME & UCBL \\
\hline 2007 & 6.32 & 6.80 & 8.20 \\
\hline 2008 & 5.13 & 6.51 & 7.32 \\
\hline 2009 & 5.88 & 8.20 & 7.74 \\
\hline 2010 & 6.00 & 6.15 & 7.72 \\
\hline 2011 & 6.17 & 6.16 & 7.72 \\
\hline \multicolumn{4}{|c|}{ Capital Adequacy Ratio (CAR) (\%) } \\
\hline 2007 & 10.19 & 11.50 & 09.27 \\
\hline 2008 & 10.39 & 10.88 & 10.34 \\
\hline 2009 & 13.16 & 14.71 & 09.22 \\
\hline 2010 & 11.49 & 11.69 & 06.30 \\
\hline 2011 & 11.96 & 12.49 & 10.93 \\
\hline \multicolumn{4}{|c|}{ Size of bank } \\
\hline 2007 & 17.28 & 25.10 & 24.63 \\
\hline 2008 & 24.38 & 25.42 & 24.89 \\
\hline 2009 & 24.68 & 25.55 & 25.22 \\
\hline 2010 & 24.78 & 25.77 & 25.58 \\
\hline 2011 & 25.05 & 26.02 & 25.85 \\
\hline \multicolumn{4}{|c|}{ Net Working Capital (NWC) (In billions Taka) } \\
\hline 2007 & 2.82 & 7.31 & 5.32 \\
\hline 2008 & 3.53 & 8.04 & 6.28 \\
\hline 2009 & 4.22 & 13.80 & 6.08 \\
\hline 2010 & 7.37 & 21.99 & 8.73 \\
\hline 2011 & 7.74 & 23.62 & 17.57 \\
\hline \multicolumn{4}{|c|}{ Return on Equity (ROE) $(\%)$} \\
\hline 2007 & 10.31 & 26.56 & 25.98 \\
\hline
\end{tabular}




\begin{tabular}{lccc}
\hline \multicolumn{4}{c}{ Year wise performance $(2007-2011)$} \\
\hline 2008 & 12.28 & 18.39 & 17.44 \\
2009 & 22.27 & 23.93 & 16.35 \\
2010 & 22.57 & 20.85 & 27.89 \\
2011 & 08.39 & 19.25 & 18.44 \\
& Return on Assets (ROA) (\%) & \\
2007 & 0.65 & 1.75 & 1.62 \\
2008 & 0.78 & 1.11 & 1.18 \\
2009 & 1.5 & 2.25 & 1.03 \\
2010 & 1.7 & 2.34 & 1.67 \\
2011 & 0.52 & 1.84 & 1.74 \\
\hline
\end{tabular}

\section{ANALYSIS OF LIQUIDITY RISK AND ITS MANAGEMENT FACTORS} (ISLAMIC BANKS)

\begin{tabular}{|c|c|c|c|}
\hline \multicolumn{4}{|c|}{ Year wise performance (2007-2011) } \\
\hline \multicolumn{4}{|c|}{ Liquidity risk $(\%)$} \\
\hline Year & EXIM & SHAHJALAL & SIBL \\
\hline 2007 & 8.96 & 6.71 & 6.93 \\
\hline 2008 & 9.62 & 7.12 & 5.60 \\
\hline 2009 & 10.69 & 6.92 & 5.54 \\
\hline 2010 & 8.92 & 9.13 & 8.14 \\
\hline 2011 & 11.49 & 8.81 & 6.75 \\
\hline \multicolumn{4}{|c|}{ Capital Adequacy Ratio (CAR) $(\%)$} \\
\hline 2007 & 11.23 & 09.78 & 10.22 \\
\hline 2008 & 10.79 & 12.32 & 09.58 \\
\hline 2009 & 11.18 & 13.98 & 11.02 \\
\hline 2010 & 09.95 & 11.40 & 09.33 \\
\hline 2011 & 10.88 & 10.08 & 13.17 \\
\hline \multicolumn{4}{|c|}{ Size of Bank } \\
\hline 2007 & 6.51 & 3.34 & 1.52 \\
\hline 2008 & 7.22 & 4.33 & 1.05 \\
\hline 2009 & 7.68 & 5.99 & 2.79 \\
\hline 2010 & 14.18 & 7.66 & 3.20 \\
\hline 2011 & 16.83 & 10.94 & 4.56 \\
\hline \multicolumn{4}{|c|}{ Net Working Capital (NWC)(In billions Taka) } \\
\hline 2007 & 24.66 & 24.06 & 23.92 \\
\hline 2008 & 24.94 & 24.53 & 24.11 \\
\hline 2009 & 25.14 & 24.79 & 24.41 \\
\hline 2010 & 25.45 & 25.09 & 24.72 \\
\hline 2011 & 25.58 & 25.40 & 25.15 \\
\hline \multicolumn{4}{|c|}{ Return on Equity (ROE) (\%) } \\
\hline 2007 & 23.02 & 23.02 & 9.09 \\
\hline 2008 & 21.98 & 22.67 & 10.82 \\
\hline 2009 & 25.09 & 21.73 & 12.13 \\
\hline
\end{tabular}




\begin{tabular}{llrl}
\hline \multicolumn{4}{c}{ Year wise performance $(2007-2011)$} \\
\hline 2010 & 27.78 & 30.70 & 15.25 \\
2011 & 13.94 & 16.29 & 11.03 \\
& Return on Assets (ROA) $(\%)$ & \\
2007 & 1.81 & 2.28 & 0.61 \\
2008 & 2.49 & 1.80 & 0.67 \\
2009 & 2.01 & 1.81 & 1.07 \\
2010 & 3.05 & 2.62 & 1.17 \\
2011 & 2.67 & 1.19 & 1.22 \\
\hline
\end{tabular}

APPENDIX A3

PEARSON CORRELATION COEFFICIENTS

\begin{tabular}{|c|c|c|c|c|c|}
\hline \multicolumn{6}{|c|}{ (Conventional banks) } \\
\hline & Size of bank & $\begin{array}{l}\text { Net working } \\
\text { Capital }\end{array}$ & $\begin{array}{l}\text { Return on } \\
\text { Equity }\end{array}$ & $\begin{array}{c}\text { Capital } \\
\text { Adequacy } \\
\text { Ratio }\end{array}$ & $\begin{array}{c}\text { Return on } \\
\text { Assets }\end{array}$ \\
\hline Size of bank & 1 & .472 & .450 & .129 & .190 \\
\hline Net working & & 1 & .181 & .328 & .192 \\
\hline \multicolumn{6}{|l|}{ Capital } \\
\hline Return on & & & 1 & -.091 & .235 \\
\hline \multicolumn{6}{|l|}{ Equity } \\
\hline Capital & & & & 1 & .498 \\
\hline \multicolumn{6}{|l|}{ Adequacy } \\
\hline \multicolumn{6}{|l|}{ Ratio } \\
\hline \multicolumn{6}{|l|}{$\begin{array}{l}\text { Return on } \\
\text { Assets }\end{array}$} \\
\hline Assets & & & & & \\
\hline \multicolumn{6}{|c|}{ (Islamic banks) } \\
\hline & Size of bank & $\begin{array}{l}\text { Net working } \\
\text { Capital }\end{array}$ & $\begin{array}{l}\text { Return on } \\
\text { Equity }\end{array}$ & $\begin{array}{c}\text { Capital } \\
\text { Adequacy } \\
\text { Ratio }\end{array}$ & $\begin{array}{c}\text { Return on } \\
\text { Assets }\end{array}$ \\
\hline Size of bank & 1 & $.871 * *$ & .324 & .193 & $.567 *$ \\
\hline Net working & & 1 & .353 & -.006 & $.709 * *$ \\
\hline \multicolumn{6}{|l|}{ Capital } \\
\hline Return on & & & 1 & .128 & $.785 * *$ \\
\hline \multicolumn{6}{|l|}{ Equity } \\
\hline Capital & & & & 1 & .080 \\
\hline \multicolumn{6}{|l|}{ Adequacy } \\
\hline \multicolumn{6}{|l|}{ Ratio } \\
\hline Return on & & & & & 1 \\
\hline \multicolumn{6}{|l|}{ Assets } \\
\hline $\begin{array}{l}\text { **Correlatior } \\
* \text { Correlation }\end{array}$ & $\begin{array}{l}\text { significant at } \\
\text { ignificant at th }\end{array}$ & $\begin{array}{l}0.01 \text { level (2 } \\
0.05 \text { level }(2-\mathrm{t}\end{array}$ & & & \\
\hline
\end{tabular}

